\title{
Out of the Cage and into the Barn: Supermarket Power, Food System Governance and the Regulation of Free-Range Eggs
}

\author{
Christine Parker* and Gyorgy Scrinis**
}

Griffith Law Review, 2014, 21(2) 318-347

\begin{abstract}
The highly concentrated nature of food retailing in Australia gives supermarkets considerable control over the interface between consumers and producers. Legal and regulatory commentary debates what can and should be done about the market dimensions of supermarket power. This paper shows that Australian supermarkets are amassing not only economic power but also political power in the food system. The paper makes this argument by reference to the two major supermarkets' initiatives in the regulatory space around food labelling, specifically the contested meaning of free range eggs. The paper examines how the supermarkets are using their market power to create private standards for suppliers of own brand products that set the meaning of "free range" for consumers too. This entrenches supermarkets' market share as well as their political power as food authorities.
\end{abstract}

* Professor, Law Faculty, Monash University. Email:

christine.parker@monash.edu.au

** Lecturer, Agriculture and Food Systems, School of Land and Environment, Melbourne University.

Acknowledgements: The authors are grateful to Carol Richards for very helpful comments on an earlier draft of this paper, and to Caron Beaton-Wells and Jane Dixon for useful early conversations. Carly Brunswick and Josie de Costa's assistance with the research for this paper was also tremendously helpful. 


\section{INTRODUCTION}

The market power and conduct of Australia's two dominant supermarkets is under scrutiny. ${ }^{1}$ The Australian Competition and Consumer Commission (ACCC) is investigating allegations of "unconscionable conduct in their dealings with their suppliers" and whether they are "misusing their market power by discriminating in favour of their own brand products in order to deter or prevent suppliers of proprietary products from engaging in competitive conduct", ${ }^{2}$ and recently announced enforcement action against Coles for allegedly using misleading information and unfair tactics to request rebate payments from suppliers. ${ }^{3}$ In late 2013 the ACCC accepted enforceable undertakings from the two major supermarkets addressing concerns with the distorting effects of the supermarkets' shopper docket petrol discount vouchers on the retail petrol market, and later took action for alleged breaches of these undertakings. ${ }^{4}$ The ACCC has also taken action recently against Coles and Woolworths respectively for misleading and deceptive claims relating to whether bread was baked fresh that day and the safety of products. ${ }^{5}$

Commentators have suggested that the two major supermarkets have too much market power and that they are abusing this market power in their terms of trade with suppliers and the choices available to consumers. ${ }^{6}$ The first part of this paper makes the case that supermarkets have been growing their political power as "food authorities" " alongside their market power. It shows that this political power has at least three "faces": direct or "instrumental" power to set prices and conditions of supply; regulatory or "structural" power to set private rules and shape public regulations; and, finally "discursive" or cultural power to influence ideas about how

\footnotetext{
${ }^{1}$ Round (2006); Taylor (2013).

2 ACCC (2013) pp2.

${ }^{3}$ ACCC, 'ACCC takes action against Coles for alleged unconscionable conduct towards its suppliers' http://www.accc.gov.au/media-release/accc-takes-action-against-coles-for-alleged-unconscionableconduct-towards-its-suppliers 5 May 2014; 'ACCC accuses Coles of breaching consumer law' The Australian 6 May 2014 http://www.theaustralian.com.au/business/latest/coles-breached-consumer-lawaccc/story-e6frg90f-1226905745237.
}

${ }^{4}$ ACCC, 'Coles and Woolworths undertake to cease supermarket subsidised fuel discounts' http://www.accc.gov.au/media-release/coles-and-woolworths-undertake-to-cease-supermarketsubsidised-fuel-discounts 6 December 2013. ACCC, 'ACCC takes action against Coles and Woolwoths for allegedly breaching fuel shopper docket undertakings', http://www.accc.gov.au/media-release/accctakes-action-against-coles-and-woolworths-for-allegedly-breaching-fuel-shopper-docket-undertakings, 25 February 2014. The individual undertakings are available online on the ACCC Undertakings Register at http://registers.accc.gov.au/content/index.phtml/itemId/6029.

5 ACCC, IACCC wins Federal Court case against Coles over bread 'baked today, sold today' claims' http://www.abc.net.au/news/201406-18/coles-loses-case-over-baked-bread-claims/553276618 June 2014; ACCC, 'ACCC takes action against Woolworths for unsafe products' http://www.acc.gov.au/media-release/accc-takesaction-against-woolworths-for-unsafe-products 17 September 2014.

${ }^{6}$ See ACCC (2008), Round (2006), Taylor (2013).

${ }^{7}$ Dixon (2007); see also Burch et al (2013) pp216; Konefal et al (2005). 
the food system should operate. ${ }^{8}$ The second and third parts of the paper illustrate and specify these three faces of supermarkets' political power by reference to Coles and Woolworths own brand "free range" labelled egg lines.

The second part of the paper shows how the two supermarkets have used their direct market power to set terms and conditions of supply for their own brand products to step into the contested regulatory space for "free range" labelling. By creating and enforcing their own private regulatory standards for free range eggs, Coles and Woolworths have entrenched and stabilised their market share and also their authority over the food production system and the choices available to consumers. ${ }^{9}$

The third part of the paper suggests that Coles and Woolworths are further engaged in a discursive campaign that seeks to establish their cultural authority over what food should be available, how it should be produced and how to mediate between producer interests and consumer concerns. This is particularly evident in the development of new lines such as "free range" eggs to respond to emerging consumer environmental, health and animal welfare concerns. Supermarkets seek to establish their cultural authority over consumer values issues such as "free range" in order to legitimate their regulatory power and thus secure their extraordinary market power.

The paper concludes by suggesting that any inquiry into supermarket power must address all three faces of power, not merely their direct, economic power over the retailing of food.

\section{SUPERMARKETS AS FOOD AUTHORITIES}

For much of the twentieth century, agricultural input and food manufacturing companies were the dominant authorities in food systems, using their control of the production and distribution process to dictate terms of trade to farmers, retailers and consumers. By the 1980s, however, increasing concentration in the retail sector gave supermarkets the dominant position. ${ }^{10}$ Supermarkets' control of the interface between the mass of food producers and consumers has made them pre-eminent "food authorities"11 in a food regime characterised by the dominance of many large scale, often global corporations. ${ }^{12}$

Australian supermarkets' power as market authorities is particularly obvious. Their direct economic power to set terms of trade with suppliers and edit the choices available to consumers is clear - and contested. Australia has one of the higher levels of concentration of food retailing in the world, with the two dominant supermarket chains, Woolworth and Coles, often described as a duopoly. These two chains control

\footnotetext{
${ }^{8}$ Clapp (2012) pp 113; Fuchs \& Clapp (2009) pp7-10.

${ }^{9}$ Burch et al (2013) pp216; see also Konefal et al (2005).

${ }^{10}$ Burch \& Lawrence (2007); Konefal et al (2005); Richards et al (2012, 2013).

${ }^{11}$ Dixon (2007); see also Burch et al (2013) pp216; Konefal et al (2005).

${ }^{12}$ McMichael \& Friedmann (2007).
} 
around $60 \%$ of the grocery market, including up to $80 \%$ of packaged groceries and between $45 \%$ and $60 \%$ of fresh food. ${ }^{13}$ By comparison the four leading supermarket chains in the United Kingdom and in France account for $67 \%$ and $53 \%$ of their grocery markets respectively. ${ }^{14}$

The Australian supermarket duopoly have systematically used their market power to place pressure on the terms of trade offered to suppliers. This includes reductions in prices to suppliers, delayed payments, and passing on costs associated with quality auditing and supermarket 'specials' to suppliers. ${ }^{15}$ In the "milk wars", for example, the supermarkets were accused of driving down the price paid at the farm-gate in order to offer lower prices to consumers and therefore undercut competitors. ${ }^{16} \mathrm{~A}$ current ACCC inquiry is investigating evidence of situations where this has gone beyond legitimate market behaviour to "unconscionable conduct" or "misuse of market power". The ACCC have commented that even though suppliers are reluctant to publicly complain about the two dominant supermarkets, there is a high degree of consistency in their confidential allegations of unacceptable business practices. Their allegations include complaints about the supermarkets making persistent demands for additional payments, imposing penalties not specified in the terms of trade, threats to remove products from shelves or otherwise disadvantage suppliers if payments are not made, and failure to pay prices agreed with suppliers. ${ }^{17}$

Supermarkets' direct or "instrumental" power to set prices and conditions of supply based on their market power is however just the most obvious of the "faces" of power that corporations can exercise in the food system. ${ }^{18}$ This power is not just economic; it is also political and it has two other faces: regulatory or "structural" power to set private rules and shape public regulations, institutions and norms under which food is produced and supplied; and "discursive" or cultural power to influence ideas about how the food system should operate. The following subsections describe these other two faces of supermarket power in the contemporary food system.

\section{Supermarkets as regulatory authorities}

Supermarkets' power over suppliers is facilitated by the trend for supermarkets to vertically coordinate and integrate their supply chains, by-passing wholesalers and other intermediaries, and instead entering into direct contracts with farmers and food manufacturers. Supermarket control of supply chains means that they are also able to shift the practices of mainstream producers to meet their own standards. At first supermarkets used this buying power to set production, biosafety and traceability standards for fresh produce, at times higher than those set by government regulation. ${ }^{19}$

\footnotetext{
${ }^{13}$ ACCC (2008); Mortimer (2013).

${ }^{14}$ Davis \& Reilly (2010).

${ }^{15}$ Burch et al (2012); Richards et al (2012).

16 Taylor (2013), pp 279.

17 ACCC (2013) p2.

${ }^{18}$ Fuchs \& Clapp (2009), 7-10.

${ }^{19}$ Bain et al (2005); Fuchs et al (2011).
} 
Governments also leave much food safety regulation to supermarkets to implement and enforce in practice. ${ }^{20}$

Since the 1990s supermarkets have increasingly engaged in a second phase of higher level quality standardisation beyond basic guarantees of food safety. In this second phase of standardisation, supermarkets are using own-brand products in particular to differentiate themselves from their competitors on the basis of the qualities of their product offerings.

Supermarket own brand products were initially targeted at the budget end of the market through the provision of plain label unprocessed staples. But as the grocery retail market concentrates, and price competition between the various grocery behemoths has also intensified, brand differentiation on the basis of the quality of own brand labelled foods, is an increasingly important competitive strategy. ${ }^{21}$ Thus Australian supermarkets have followed UK and European supermarkets in using own brand labels to supply food that is branded as organic, environmentally sustainable, healthy, fairly traded, and humanely raised, as well as value-added products such as gourmet prepared meals. ${ }^{22}$ As of 2011, the latest figures publicly available, supermarket own-brand products now account for $25 \%$ of retail sales in Australia, ( $50 \%$ of the retail eggs market) and this market share is rapidly growing.$^{23}$

This further consolidates supermarket power over suppliers - and creates a situation in which supermarkets can translate a market based power to set terms of trade for suppliers into structural power to set and enforce private standards and thus become (private) regulators of the food system itself. ${ }^{24}$ In the long term the supermarkets may create a situation in which most products are either own brand (rendering suppliers completely subject to supermarket control) or niche brand name products (that come and go with consumer demand as interpreted by the supermarkets themselves- and thus also subject to supermarket control).

Supermarkets' structural power over suppliers allows these corporations to act as regulatory authorities mediating between the concerns of consumers and the interests of producers. Supermarkets now selectively translate various social, health, environmental and consumer demands into their own requirements on food suppliers and producers. ${ }^{25}$ The supermarkets thus use their market power via retail concentration and own brand products to unsettle and undermine the power and influence formerly enjoyed by other actors in the food system. For example, the ban on genetically modified (GM) foods by some supermarkets in the UK in the early 2000s indicated their willingness to not only respond to apparent consumer concerns

\footnotetext{
${ }^{20}$ Fuchs et al (2011); Fulponi (2006).

${ }^{21}$ Davey \& Richards (2013); Konefal et al (2005).

${ }^{22}$ Goodman (2003); Harvey et al (2004); Konefal et al (2005).

${ }^{23}$ Outlaw (2012); Merret \& Smith (2012).

${ }^{24}$ Fuchs et al (2011).

${ }^{25}$ Friedmann (2005); McMichael \& Friedmann (2007); see also Smith et al (2010).
} 
about GM foods, but also to move against the interests of other corporations in the food system, in this case the seed-chemical corporations. ${ }^{26}$

Initiatives by supermarkets to introduce higher animal welfare standards can also be seen as a response to the intransigence of mainstream producer organisations in meeting changing consumer expectations and a pre-emption of potential government regulation, as we show below in relation to "free range" eggs. Indeed supermarkets' own private standards may shape industry-wide standards and consumer expectations regarding food qualities and the price that customers are willing to pay for them. In this way private supermarket standards may displace or even pre-empt public government standards. Thus supermarkets become regulatory authorities.

\section{Supermarkets as cultural authorities}

Friedmann emphasises the selective nature of this corporate engagement with the demands of consumers and activists within what she refers to as the contemporary 'corporate-environmental food regime'. ${ }^{27}$ The retail-led reorganization of food supply chains converges with some of the demands of environmental and other movements that resist intense industrial food production, while at the same time maintaining the legitimacy of corporate domination of the food chain, and indeed creating new products and markets for the supermarkets. ${ }^{28}$ Governance and corporate social responsibility theorists have similarly shown that large companies often create private certification standards and labelling logos in order to appropriate and encompass resistance and criticism. When successful, these private standards typically make small incremental improvements that selectively address and quieten activist and consumer concerns. They do so by creating new "moral" products and markets, eg fair trade or sustainability certified products and ethical investment portfolios, that legitimate the businesses that adopt them and at the same time maintain or expand their market reach. ${ }^{29}$

Corporations thus deploy discursive power to persuade government, the public and other corporate actors that that they are deploying private regulatory authority to legitimately address public concerns about environmental sustainability and corporate social responsibility. The third part of this paper shows how supermarkets have used public relations and marketing in a similar attempt to exercise discursive power over the meaning of "free range" eggs and thus support their own claims to be the legitimate regulatory authority over what counts as "free range".

Friedmann argues that supermarkets' quality, above-standard and audited goods are often primarily available only to privileged consumers able to afford them, thereby accentuating the bifurcation of global supply chains in which the very same corporations also supply cheaper, mass-produced, "standard edible commodities" to

\footnotetext{
${ }^{26}$ Wilkinson (2002).

${ }^{27}$ Friedmann (2005).

${ }^{28}$ Jackson et al (2007).

${ }^{29}$ Cashore et al (2011); Shamir (2008).
} 
the poor. ${ }^{30}$ An effect of this dynamic is that a two-tiered system of production, distribution and consumption may be established, divided into cheap, mass-produced, lower-standard markets versus higher priced, niche, and higher-standard markets. This can occur both within and between countries. In the UK, for example, it is the high end supermarkets such as Sainsbury's and Marks and Spencers that stock higher animal welfare products, while more downmarket chains offer less animal welfare responsive products. ${ }^{31}$ Overall more animal welfare conscious brands appear to be available in the UK than in Australia until recently. ${ }^{32}$ But for alternative products savvy consumers in both countries and throughout the western world often go to farmers' markets, specialist organic and wholefoods stores, or they source food through other methods such as box schemes, direct from farmer or through growing and swapping. ${ }^{33}$

It is possible that the contemporary dominance of supermarkets over food supply chains, combined with their tendency towards higher food standards, may result in supermarkets driving higher standards for wealthy and poor consumers alike, at least in Australia where only two chains dominate the market and therefore must cater to all consumers. Is it possible that supermarket's pre-emption of regulatory authority can govern in the interests of all? The remainder of this paper critically examines the way the two dominant Australian supermarkets are using their market power to create regulatory authority over "free range" eggs.

The next part shows how the supermarkets are using their market power to set the terms of supply for own brand products that respond to consumer demand for higher welfare "free range" eggs. Their exercise of regulatory power over food production thereby aims to complement and legitimate their extensive market power. The third part goes on to show how the supermarkets are using cultural power, in turn, to legitimate their regulatory authority over both suppliers and the choices available to consumers.

\section{THE CREATION OF SUPERMARKET REGULATORY AUTHORITY OVER "FREE RANGE"}

In 2013 both of Australia's two dominant supermarket chains loudly announced plans to improve animal welfare standards for a range of products, particularly own brand eggs as a response to their reading of consumer demand for higher welfare standards:

We know that many Australians want to feel good about the food they eat. So we're proud that all Coles brand eggs are cage free; they are now either barn laid or free range. Barn Laid and Free range hens are free to roam around, perch and dust bathe; all of which are natural behaviors. This

\footnotetext{
${ }^{30}$ Friedmann (2005).

31 Miele et al (2005). See for example, J Sainsbury plc, 'Animal Welfare' http://www.jsainsbury.co.uk/responsibility/20x20/animal-welfare/.

${ }^{32}$ Contrast Miele et al (2005) with Parker et al (2013).

${ }^{33}$ Parker et al (2013).
} 
initiative means that 350,000 hens will now never be caged. ${ }^{34}$

Woolworths customers have told us that they want help to make healthier food choices. We're really excited about working with ["much-loved chef and fresh food campaigner, Jamie Oliver"] to help Australia live and cook well by choosing fresh options, all while keeping the shopping budget under control.... As part of the partnership, Jamie Oliver has been working with Woolworths on a number of significant changes that ... include phasing out all cage eggs sold in-store by 2018, including those used in Own Brand products. $^{35}$

These statements indicate that, like many large food retailers, Coles and Woolworths want to be seen to be responsive to a range of health and welfare values voiced by their customers. ${ }^{36}$ They do so by exercising regulatory authority over suppliers.

Coles and Woolworths only began focusing on animal welfare and quality initiatives in recent years in response to ongoing consumer concern reported in the media, and their own market research. ${ }^{37}$ Since 2011 all Coles fresh beef has been advertised as "no added hormones"; and as of 2013 all Coles brand pork is "sow-stall free" and all own brand eggs are "cage-free". From January 2014 all Coles brand fresh chicken meat is Royal Society for the Prevention of Cruelty to Animals (RSPCA) approved. ${ }^{38}$

\footnotetext{
34 Quotation from Coles Pty Ltd, 'Cage Free Eggs', http://www.coles.com.au/helping-australiagrow/responsible-sourcing-and-sustainability/cage-free-eggs,. A media release dated October 2012 announces the change: Coles, 'Coles Helping Australian with Better Animal Welfare at No Added Cost to Consumers', http://www.coles.com.au/Portals/0/content/pdf/News/Sow\%20Stall\%20and\%20Caged\%20Eggs\%20M edia\%20Release\%200ct\%202012.pdf. Coles and Woolworths websites were monitored as part of the research for this paper. Full copies of all Coles and Woolworths websites and dates available are archived with the authors and available upon request.
}

35 Quotation from Woolworths press release dated 4 October 2013: Woolworths Ltd, 'Woolworths and Jamie Oliver to Inspire a Healthier Australia', http://www.woolworthslimited.com.au/icms_docs/137207 Woolworths and Jamie Oliver to inspire to_a healthier_Australia.pdf, 16 January 2014 ..

${ }^{36}$ Friedmann (2005); Jackson et al (2007).

${ }^{37}$ The authors' interview with a spokesperson from one of the major supermarkets indicated that the supermarkets introduced sow-stall free pork in response to media activism and consumer concern about misleading "bred free range" claims on pork products in 2010 [Stock \& Land, 'Tas bans sow stalls' http://www.stockandland.com.au/news/agriculture/cattle/general-news/tas-bans-sowstalls/1856159.aspx 11 June 2010; Stock \& Land, 'Court dismisses pig cruelty charges' http://www.stockandland.com.au/news/agriculture/agribusiness/general-news/court-dismisses-pigcruelty-charges/1853781.aspx 11 June 2010; Tasmanian Times, 'Coles urged to extend sow stall ban' http://www.tasmaniantimes.com/index.php/article/coles-urged-to-extend-sow-stall-ban 6 July 2010; Pig Progress, 'Pig welfare: a contentious issue for Australia's farmers' http://www.pigprogress.net/Growing-Finishing/Environment/2011/5/Pig-welfare-A-contentious-issuefor-Australias-farmers-PP007410W/ May 30 2011. But note that the Tasmanian sow stall ban seems to have been overturned in 2013: ABC News Online, 'Minister accused of backflip on sow stall ban in Tasmanian piggeries' http://www.abc.net.au/news/2013-08-05/minister-accused-of-backflip-on-sowstall-ban/4864564 Monday 5 August. Supermarkets in the UK had introduced animal welfare products several years earlier - see below.

${ }^{38}$ Coles, 'Media Release: Coles Brand Fresh Chicken Now 100\% RSPCA Approved' http://medianet.com.au/releases/release-details?id=792558, 3 January 2014. 
In 2013 Woolworths announced that they would phase out all caged eggs from sale and that they would move to RSPCA or equivalent standards for all fresh chicken meat sold in store. ${ }^{39}$ In September 2014 they announced no cage eggs would be sold in any store in the Australian Capital Territory effective immediately. ${ }^{40}$

\section{Animal welfare standards: a contested regulatory space}

While factory farming, intensive production and confinement systems have been growing globally, there have also been counter-trends to develop parallel systems for more humane forms of animal production, and to increase the base-line welfare of animals in conventional-intensive systems. Australian animal welfare advocates, such as Animals Australia and the RSPCA, have long campaigned for a complete ban on caged egg production throughout Australia, and, in the meantime, for consumers to "buycott" caged eggs and other intensively produced animal food products. ${ }^{41}$ Alternative, usually small scale, producer networks are also developing systems and support communities for free range, sustainable and pastured production. ${ }^{42}$

In other countries governments are also regulating to increase baseline animal welfare standards. As of 2012 barren "battery" cage systems for egg production are now prohibited in the European Union and producers may use only "enriched" or "furnished" cages or non-cage systems. ${ }^{43}$ There are similar developments in some parts of the United States in relation to battery cages, ${ }^{44}$ and in the European Union in relation to sow stalls. ${ }^{45}$ However retailer and third-party certification systems often

39 Based on the author's own monitoring of Coles and Woolworths' websites and advertising. Full details of websites and sources available from the authors upon request.

${ }^{40}$ ABC News, 'Woolworths removes caged eggs from ACT stores, drawing mixed response from animal welfare groups' http://www.abc.net.au/news/2014-09-04/woolworths-will-only-sell-free-range-eggs-incanberra/5718362 4 September 2014.

41 See RSPCA, 'Hens Deserve Better: Behaviour' http://www.hensdeservebetter.org.au/thedetails/behaviour.html 2012 and Make It Possible, 'Take Action - Here's How We End Factory Farming' http://www.makeitpossible.com/take_action/ 17 January 2014. .

${ }^{42}$ See e.g. Weber et al (2008). See the alternative standards summarised in Table 1.

43 Council of the European Union (1999); see also Appleby (2003). In enriched cages hens must have at least 750 square centimetres of cage area, nests, perches, litter for pecking and scratching, and unrestricted access to a food trough. In non-cage systems hens are housed in open barns with nests, perches, and litter for pecking and scratching, stocking density does not exceed nine laying hens per square metre of useable area indoors, and outdoor access may be provided but is not necessary.

\footnotetext{
${ }^{44}$ California passed legislation in 2008 requiring the phasing out of production of eggs via battery cages by 2015, and in 2010 it legislated to prohibit the sale of battery cage eggs. Michigan and Ohio, both large egg-producing states, have passed similar legislation to phase out battery cage production, and Massachusetts, Washington, Arizona, and Oregon are considering such legislation. In 2011 the Humane Society of the United States and United Egg Producers (the U.S. egg industry association) jointly drafted a federal bill that would ban battery cages and allow only enriched cages or non-cage systems (H.R.3798/S.3239): see United Egg Producers, 'Support the egg bill' http://www.eggbill.com 2012.

${ }^{45}$ Council of the European Union (2008).
} 
pre-empt governmental adoption of higher animal welfare standards. ${ }^{46}$ In 1997 in the UK, Marks and Spencer was the first retailer to sell only free-range eggs, and by 2002 was exclusively using free-range eggs in the preparation of all processed food. ${ }^{47}$ McDonalds in the UK advertises that it uses only free range eggs and uses its own certification system to define and monitor animal welfare. ${ }^{48}$

Australian governments only minimally regulate animal welfare in food production. The Model Codes of Practice for the Welfare of Animals ${ }^{49}$ are governmentally created but largely non-mandatory best practice guides.50 The 1999 European Union directive requiring the phasing out of battery cages did prompt Australian governments to consider whether they should follow suit. But in 2000 the combined federal and state agriculture ministries comprehensively rejected the idea of banning cages and also concluded that it was not appropriate to burden industry with the cost of mandating enriched cages. ${ }^{51}$ Nor are practices that are generally considered inhumane by animal welfare advocates, such as debeaking or forced moulting, prohibited by law. Indeed the Model Codes of Practice for the Welfare of Animals effectively protects livestock producers employing these practices from prosecution under animal cruelty laws. ${ }^{52}$

Instead Australia has to date adopted an "industry-led," "consumer choice" approach in which cage versus free range eggs are differentiated and labelled by standards developed by industry. ${ }^{53}$ The 4th edition of the voluntary Model Code of Practice for the Welfare of Animals, Domestic Poultry (Primary Industries Standing Committee 2002) sets out minimal standards and very brief definitions of "cage", "barn" and "free range" production. The Australian Egg Corporation Limited (AECL) - the research, marketing and representative body for egg producers - developed an audited quality assurance standard, 'Egg Corp Assured', that is the dominant method for enforcing and certifying producer compliance with the Model Code's animal welfare standards (whichever production style the producers uses - cage, barn or free range)

\footnotetext{
${ }^{46}$ Fuchs et al (2011); Fulponi (2006).

${ }^{47}$ Miele et al (2005).

48 http://www.mcdonalds.co.uk/ukhome/whatmakesmcdonalds/questions/food/animal-welfare/whatare-mcdonalds-animal-welfare-standards-and-policies.html last accessed 8 February 2014. Australian McDonalds only recently announced it would phase out cage eggs by 2017: ABC Rural, 'Farm groups dubious about McDonalds move to phase out cage eggs' http://www.abc.net.au/news/2014-09-16/farmgroups-dubious-mcdonalds-phasing-out-cage-eggs/5746938 16 September 2014.
}

${ }^{49}$ Eg Primary Industries Standing Committee 2002.

50 Sharman (2009). The Model Code of Practice for domestic poultry is mandated in one state, Queensland: Animal Care and Protection Act 2001 and Animal Care and Protection Regulation 2002, regulations 2 and 3, and Schedule 1.

${ }^{51}$ SCARM Working Group (2000), pp3.

52 Sharman (2009).

53 SCARM Working Group (2000) pp4; see also PRFLLP (2011), pp 20, 33, and 48. But note that the government of the Australian Capital Territory did introduce mandatory rules for labeling of free range, barn and cage eggs in 2009 and there have been vigorous campaigns in the states of New South Wales and South Australia to introduce similar legislation in those jurisdictions. See Parker 2013. 
and also with safety regulation and general quality assurance principles (see Table 1 for comparison with other schemes).

Government regulation is limited to consumer protection enforcement responses to complaints about particular instances of misleading and deceptive conduct in egg labelling. ${ }^{54}$ There is no specific government regulation of what can be claimed on the labels of animal products such as the meaning of "free range" or "organic". 55 This means that the regulation of animal welfare in the production and labelling of food in Australia is a fragmented and contested space with retailers, producers and suppliers (or their industry bodies), as well as activist consumer and animal welfare groups, all seeking to influence industry practice and consumer expectations and understandings. A variety of competing certification and labelling standards developed by industry, NGOs, and now supermarkets, attempt to define "humane", "animal welfare" approved and "organic" production practices and label and brand products accordingly. Table 1 summarises the main private certification and logo standards for "higher welfare" 56 or "free range" eggs in Australia. ${ }^{57}$ As Table 1 shows, the schemes with the highest standards and strictest definitions of free range are operated by farmers associated with the Humane Choice certification scheme and the Free Range Farmers Association of Victoria. The major Australian organic accreditation agencies also require free range production, and adopt high standards of animal welfare. By contrast, the RSPCA approved scheme sets out a medium level of animal welfare protection (see Table 1).

[Table 1 about here.]

\section{A regulatory contest over "free range"}

Until 2012 the Egg Corp Assured scheme operated by the AECL dominated the field. Coles and Woolworths and some of their smaller competitor retailers require own brand eggs (and also brand name eggs in the case of Coles) to be accredited to this standard as a matter of quality assurance. ${ }^{58}$ None of the alternative, stricter standards

\footnotetext{
54 The Australian Competition and Consumer Commissioner have taken enforcement action in a number of cases where egg suppliers mislabelled cage eggs as free range. They have also taken enforcement action against a number of meat poultry suppliers who described chickens and ducks as "free to roam" or "open range" when in fact they were largely confined in barns with their movement obstructed by other birds (see NSW Fair Trading (2013), pp17-18).
}

${ }^{55}$ Although there are various standards for "organic" including the export standard initiated by the Australian government (the National Standard for Organic and Biodynamic Produce, Edition 3.4, July 2009 which is considered the baseline for he various private organic certification standards.

56 A term used by Jamie Oliver in recipes: see e.g. Jamie Oliver, 'Using the whole chicken' http://www.jamieoliver.com/recipes/chicken-recipes/using-the-whole-chicken.

57 Based on Parker's fieldwork conducted in 2012 surveying eggs available in retail outlets throughout Australia and interviewing accreditation organisations: see also Parker (2013); Parker et al (2013).

58 The supplier requirements available on Coles and Woolworths websites (Coles (2011) 'Coles

Supplier Requirements - Food (Supplier Standard - CSR-FV3) (May 2011)'

https://www.supplierportal.coles.com.au/csp/wps/wcm/connect/colessupplier_en/csp/quality+- 
have achieved a similar scale of take up by producers, or crucially, adoption by supermarkets. The stricter the standard, the less likely they are to be stocked in Coles and Woolworths (as shown in Table 1). ${ }^{59}$

In 2012, however, Egg Corp Assured's minimalist standards for free range lost their legitimacy with both consumers and supermarkets. The AECL had sought to revise their Egg Corp Assured standard and logo to respond to ongoing activism to ban battery cages and mandate labelling of cage, barn and free range eggs and to increased consumer demand for free range eggs. ${ }^{60}$ The new standard would include a revised definition of free range that would allow a maximum outdoor stocking density of 20 000 hens per hectare or 2 hens per square metre for the required size of ranging area outside the barn). This is 8 to 26 times more than the maximum stocking densities allowed by competing voluntary accreditation and logo systems for "free range" and "organic" eggs in Australia and internationally, ${ }^{61}$ and 13 times more than the Model Code's apparent stocking density limit of 1500 hens per hectare for free range production.

Egg Corp Assured's proposed 20000 stocking density limit reflected the view of the AECL and many of its larger producer members that the (non-mandatory, but government created) Model Code states no limit for the outdoor stocking density of hens per hectare as long as hens are rotated onto different outdoor ranges (with no standard as to how often). Consumer and activist groups and small scale free range producers interpret the Code to require an absolute maximum of 1500 hens per hectare for egg production. They argue that the exception that Egg Corp Assured relies on to justify higher stocking densities where there is rotation applies only to meat chickens. ${ }^{62}$

+coles+brands/supplier+audit+requirements/food/coles+supplier+requirements+csr-fv3;

Woolworths(2013) 'WQA Quality Assurance Standard - Primary Production: Eggs - Version 8' http://www.wowlink.com.au/wps/portal/!ut/p/c0/04_SB8K8xLLM9MSSzPy8xBz9CP0os3izQB8jJydD RwMDA2djA6Mg_zDHsNBgYwN3U_2CbEdFAI9eKqI!/?WCM_GLOBAL_CONTEXT=/cmgt/wcm /connect/Content\%20Library\%20-

\%20WOWLink/WOWLink/Topic\%20Centre/StandardsCompliance/WQA/WQA\%20Standards\%20Ve rsion\%2008. ; Woolworths (2011) 'Corporate Social Responsibility Report: Closer Every Day'

http://www.woolworthslimited.com.au/icms_docs/129942_Corporate_Responsibility_Report_2011.pdf ; Woolworths (2012) 'Corporate Social Responsibility Report' http://woolworthslimited.com.au/CRReport/2012/ceos-statement.html) indicate that Coles requires Egg Corp Assured certification for all shell eggs sold in store, and RSPCA certification for all own brand barn eggs. Woolworths require Egg Corp Assured certification for all own brand eggs. Our research found that even when producers had Egg Corp Assured accreditation, they do not necessarily show the logo on their packs.

${ }^{59}$ See Parker et al 2013.

${ }^{60}$ AECL, 'Developing a new standard for Australian eggs: your questions answered' http://www.aecl.org/assets/Uploads/QA-resources/ESA-QA-A4brochure-web.pdf 2010.

${ }^{61}$ See Table 1 and ACCC, 'SA supplier penalised \$50,000 for egg substitution' http://www.accc.gov.au/media-release/sa-supplier-penalised-50000-for-egg-substitution 5 September 2012 para 82.

${ }^{62}$ ACCC (2008). 
The AECL's attempt to legitimate a stocking density of 20, 000 hens per hectare backfired by exposing the fact that, at the time, many suppliers of "free range" eggs in mainstream retailers including Coles and Woolworths were stocking at even higher densities - up to 50, 000 hens per hectare according to one report. ${ }^{63}$ Even the AECL admitted in 2012 that " $29 \%$ of free range egg production in Australia stocks at densities higher than 2 hens per square metre (20000 per hectare) on the range area", ${ }^{64}$ suggesting that a limit of 20,000 would therefore be an improvement.

Investigative journalists ${ }^{65}$ also revealed that producers were engaging in a range of questionable farming practices in order to achieve the scale and reliability of supply that the supermarkets needed and at the price the supermarkets were willing to pay. For example, "free range" layer hens were crowded into large multi-tier barns where the majority never accessed the outside, the ranges were bare and unattractive, and the hens' beaks were trimmed at an early age in order to avoid the pecking and cannibalism that is endemic where they are crowded together in stressful conditions, given little opportunity to express natural behaviours such as preening, nesting, perching, foraging and dust bathing. ${ }^{66}$

Egg Corp Assured's free range requirements barely regulate these matters. They provide for little management of vegetation and environmental conditions on the ranging area to make it attractive for hens to venture outside of the barn, no limits on the number of birds allowed in a single barn or site, and no requirement about the minimum proportion of time that they should have access to outside. The AECL proposed a stocking density of approximately 15 birds per square metre inside the barn, which is twice as dense as alternative accreditation standards (see Table 1). It would also allow animal "husbandry" practices such as beak-trimming, toe trimming, forced moulting, and the use of antibiotics and colorants in the feed, all of which are prohibited under alternative systems. There have also been claims that a significant amount of egg substitution - where cage or barn eggs (which can be more cheaply produced) are labelled and sold as "free range" (at a mark-up) has been occurring. ${ }^{67}$

\footnotetext{
${ }^{63}$ Melissa Fyfe and Royce Millar (2013) 'Coles Sets Its Own Squeezier Standard' The Age http://www.theage.com.au/victoria/coles-sets-its-own-squeezier-standard-20130303-2fefw.html 4 March 2013; see also Animal Welfare Labels, 'The argument for a national definition for 'free range' eggs' http://www.animalwelfarelabels.org.au/index.php/news/108-the-argument-for-a-nationaldefinition-for-free-range-eggs 2011. See note Error! Bookmark not defined. above.
}

${ }^{64}$ AECL, 'Fact Sheet: Free Range Stocking Densities' http://www.aecl.org/system/attachments/511/original/Free\%20range\%20stocking\%20density\%20fact\% 20sheet.pdf?1334129238 2012.

${ }^{65}$ Melissa Fyfe and Royce Millar (2013) 'Free to range or not, have supermarkets egg on their faces?' The Age http://www.theage.com.au/victoria/free-to-range-or-not-have-supermarkets-egg-on-theirfaces-20130303-2fefx.html 4 March 2013.

${ }^{66}$ Appleby \& Hughes (1991); Duncan (2001).

${ }^{67}$ ACCC, 'SA supplier penalised \$50,000 for egg substitution’ http://www.accc.gov.au/mediarelease/sa-supplier-penalised-50000-for-egg-substitution 5 September 2012; The Sunday Telegraph, 'Glensung Pty Ltd, trading as Paul Galea and Son Egg Farm sold barn laid eggs as free range' http://www.dailytelegraph.com.au/news/national/glensung-pty-ltd-trading-as-paul-galea-and-son-eggfarm-sold-barn-laid-eggs-as-free-range/story-fndo28a5-1226489837361 7 October 2012; NSW Food Authority, 'Producer Fined for Mislabelling Eggs (Media Release)' http://www.foodauthority.nsw.gov.au/news/media-releases/mr-07-Oct-12-producer-fined-mislabellingeggs/\#.UtXk4Z24Z9B 7 October 2012; The Daily Telegraph, 'South Australian egg supplier Rosie's 
In November 2012 the Australian Competition and Consumer Commission issued a lengthy preliminary report finding that Egg Corp Assured's definition of "free range" was misleading and deceptive and the AECL withdrew its proposed revision. ${ }^{68}$ In 2014 the ACCC commended action against two suppliers of Egg Corp Assured "free range" eggs for misleading and deceptive conduct, and on was recently found liable for misleading and deceptive conduct and penalised \$300, 000. ${ }^{69}$ Governments had delegated responsibility to industry self-regulation, but the producer body with its legislative mandate to develop and represent the industry had proposed a standard that failed to find legitimacy.

\section{Translating market authority into regulatory authority over "free range"}

In October 2012, Coles stepped into this regulatory controversy by announcing its own definition of free range for Coles own brand eggs would be a maximum of 10 , 000 hens per hectare outdoors, ${ }^{70}$ and that as of January 2013 they would not sell any own brand cage eggs. ${ }^{71}$ Both the cage free initiative and the Coles definition of free range were heavily advertised in store and via traditional media and the web with the tagline "all Coles brand eggs are cage free eggs" (see Illustration 1). Since March $2013^{72}$ Coles own brand eggs display the stocking density (10,000 hens per hectare) on the packaging (see Illustration 2). Coles now offers no own brand cage eggs for sale. It still sells the intermediate category of "barn laid" eggs in its own brand labelling. But barn accounts for only a small proportion of Coles own brand egg sales, and has not featured in these recent initiatives and advertising campaigns. Coles still

Free Range Eggs fined for selling cage eggs advertised as free-range’

http://www.dailytelegraph.com.au/news/national/south-australian-egg-supplier-rosies-free-frange-eggsfined-for-selling-cage-eggs-advertised-as-free-range/story-fndo2izk-1226465885334 5 September 2012.

68 ACCC (2012). The ACCC had the responsibility to review the proposed new Egg Corp Assured standard before it could be used as a trademark.

${ }^{69}$ ACCC, 'Federal Court orders $\$ 300,000$ penalty after finding 'free range' egg claims to be misleading' http://www.accc.gov.au/media-release/federal-court-orders-300000-penalty-after-finding-free-rangeegg-claims-to-be-misleading 23 September 2014, MR 233/14.

70 See press release cited at note 1 above. Coles appear to have adopted the Victorian Farmers Federation's (VFF) HenCare as one of the standards they recognise: VFF, 'HenCare Egg Standards' http://www.vff.org.au/vff/Documents/egg\%20standards.pdf; VFF, 'Coles Backs VFF's HenCare QA Program (Media Release) http://www.vff.org.au/vff/Media_Centre/Coles\%20backs\%20VFF\%E2\%80\%99s\%20HenCare\%20QA $\% 20$ program.aspx. The new Coles standard also allows 30,000 hens to be kept in a single shed, with inside densities of 12 birds per square metre (Melissa Fyfe and Royce Millar (2013) 'Coles Sets Its Own Squeezier Standard’ The Age http://www.theage.com.au/victoria/coles-sets-its-own-squeezierstandard-20130303-2fefw.html 4 March 2013).

${ }^{71}$ Coles, 'Coles Helping Australian with Better Animal Welfare at No Added Cost to Consumers', http://www.coles.com.au/Portals/0/content/pdf/News/Sow\%20Stall\%20and\%20Caged\%20Eggs\%20M edia\%20Release\%200ct\%202012.pdf, 17 January 2014.

72 Dating based on our own in store visits and Melissa Fyfe and Royce Millar (2013) 'Coles tackled on free range plan' The Sydney Morning Herald http://www.smh.com.au/environment/animals/colestackled-on-freerange-plan-20130303-2fegm.html\#ixzz2pmwxhleT 4 March 2013. 
sells brand name cage eggs and presumably still uses cage eggs in its own-brand processed and prepared foods.

[Illustrations 1 and 2 about here.]

In October 2013, Woolworths countered by announcing that by 2018 it would phase out the sale of both own-brand and branded cage eggs and cease using cage eggs as an ingredient in own brand products. ${ }^{73}$ They stated that beginning immediately all "free range" eggs sold would state the stocking density on the label, thereby providing more transparency than Egg Corp Assured certified eggs. Since around September 2013, the Woolworths Select Free Range egg carton clearly states in a prominent diamond shaped logo: "1 BIRD per metre ${ }^{2}$ outdoors equals 10,000 birds per hectare." A footnote states "A maximum hen stocking density of 10, 000 birds per hectare where hens are regularly rotated onto fresh range areas and some continuing fodder is provided." 74 (See illustration 3.)

[Illustration 3 about here.]

Because of Coles and Woolworths' market power, the egg producers supplying these supermarkets appear to have had little choice but to modify their production practices in line with the new stocking density rules. As one egg producer commented in the press,

The supermarkets, being a duopoly, are a very powerful entity and they do tend to dictate to a great degree as to how they like things to be done... In reality you have to do the density that your customers want and the customers are the major supermarkets and they have said they want 10,000 per hectare so that's what everybody seems to run at. ${ }^{75}$

Other branded egg suppliers also appear to be following Coles' and Woolworths' lead in clearly stating the stocking density on their labels: Visits to Coles and Woolworths stores showed that in February and March 2012 - before the two supermarkets' announcements about free range - only two brands had shown the stocking density clearly on the carton. By September 2013, six brands were displaying the stocking density on the carton, including the two supermarket own-brand eggs (see Table 2). All but one of these indicated a stocking density of 10, 000 or under, in line with Coles and Woolworths' standard. (See Illustrations 4a-c).

[Table 2 and Illustrations $4 \mathrm{a}$ to c about here.]

Indeed supermarkets' use of their market power to exercise regulatory authority over free range can even influence and pre-empt government regulation. Immediately after

\footnotetext{
${ }^{73}$ Currently Woolworths still offers a budget old style "home brand" cage egg line, but offer only free range and barn eggs in their "Woolworths Select" branding. Woolworths also have a third free range premium "macro" organic brand with Australian Certified Organic certification.

74 Carton bought at Woolworths, Queen Victoria Building, Melbourne on 20 September 2013.

${ }^{75}$ ABC News Online, 'A call for legislation to define 'free range' is ruffling feathers in the industry' http://www.hsi.org.au/?catID=1271 14 October 2013.
} 
Coles' announcement, the Australian state of Queensland changed its animal welfare legislation to adjust the Model Code definition of "free range" from 1500 birds per hectare outside to 10,000 hens per hectare. ${ }^{76}$ The action of the supermarkets may also be a factor justifying state governments in not legislating or enforcing higher standards for animal welfare in production despite high profile and highly popular activist campaigns to ban battery cages. Nor have the state or federal governments legislated food labelling standards that would mandate labelling of eggs according to production system and a clear definition of "free range", despite bills in a number of states to do so. ${ }^{77}$ Instead state consumer affairs ministers are proposing an industry code or mandatory information standard under the Australian Consumer Law to define "free range". ${ }^{78}$ This code is still to be drafted and provided for public consultation so it remains to be seen how willing and able the consumer affairs ministers are to take on the supermarkets and major producers in this space. It is likely that any new code will clarify the stocking density required for free range but otherwise maintain the unsatisfactorily minimal standards for free range in the Model Code. Moreover, a code under the Australian Consumer Law will be largely enforced by reactive response to consumer and competitor complaints, and only where consumer regulators choose to prioritise action. By contrast, a labelling standard under food labelling law could, at least in theory, be subject to proactive monitoring by food safety regulators with power to inspect premises.

\section{THE CONTEST FOR LEGITIMACY AS A FOOD AUTHORITY}

Coles and Woolworths cage free egg initiatives suggests that supermarkets may indeed take on regulatory authority to govern the supply chain to drive positive welfare changes in the way eggs are produced. But the supermarkets' definition of "free range", and their very authority to regulate that meaning, are heavily contested by producers, animal welfare advocates and consumer activists. Indeed it appears that supermarkets' cage free initiatives have done little more than appropriate animal welfare discourse and alternative production methods into a misleadingly labelled "free range" egg that is produced and sold via an industrial, intense, concentrated model of business. ${ }^{79}$

\footnotetext{
${ }^{76}$ Australian Food News, 'South Australian Government 'Disappointed' by Changes to Queensland 'Free Range' Egg Standard' http://www.ausfoodnews.com.au/2013/07/24/south-australiangovernment-\%e2\%80\%98disappointed \%e 2\%80\%99-by-changes-to-queensland-\%e2\%80\%98freerange\%e2\%80\%99-egg-standard.html 24 July 2013.
}

\footnotetext{
${ }^{77}$ See for example the bills introduced in several states to mandate labelling of production system for eggs: Truth in Labelling (Free Range Eggs) Bill (NSW) 2013; Free Range Eggs Labelling Bill (WA) 2013; Food (Labelling of Free Range Eggs) Bill Amendment Bill (SA) 2012; Egg Labelling and Sale Bill (Tas) 2013

78 ABC TV News, "Free-range eggs: States, territories to try to agree on national code to stamp out misleading products", http://www.abc.net.au/news/2014-06-12/states-territories-asked-to-agree-onfree-range-egg-standard/5519190, Thursday 12 June.

${ }^{79}$ See ACCC (2012).
} 
Coles and Woolworths are not just informing consumers of their products but also seeking to persuade the public, producers and governments of the legitimacy of their own authority over the food system - to set standards for production practices and edit the choices available to consumers. They are engaging in a contest for discursive and persuasive power over the very meaning of "free range". The following subsections show that Coles and Woolworths are using three interrelated communication strategies to argue that they are trustworthy and legitimate authorities over the appropriate meaning of "free range". First they seek to appropriate the governmental role of balancing varying stakeholder interests suggesting they are the most legitimate arbiter of conflicting supplier and consumer perspectives. Second they garner the public approval of animal welfare advocacy agencies for their initiatives in order to acquire an "ethical halo" over their attempts to define free range. Third they hire accessible, activist celebrity chefs to act as spokespersons and thus seek to persuade consumers they can be trusted to keep on being responsive to animal welfare and other consumer values and concerns about the way food is produced and priced.

\section{Appropriating a governmental role of balancing stakeholder interests}

Coles in particular is positioning itself as legitimate mediator between the high aspirations of animal welfare advocates who believe battery cages should be banned, egg producers who need to provide reliable, large enough supply, and consumers who want to express their identity through ethical choices, but are also concerned with value, affordability and convenience. ${ }^{80}$ The very notion of setting the stocking density for free range at 10, 000 hens per hectare rather than either 1500 (as understood by consumer and animal welfare advocacy groups) or 20, 000 (as proposed by the AECL) also gives the message that Coles and Woolworths are the legitimate mediators between competing and conflicting stakeholder needs. In one media release, Coles states,

we have issued a standard that sets out a maximum stocking density of 10,000 birds a hectare. ... We came to this figure after consulting with industry and welfare groups, and we believe it strikes the appropriate balance between animal welfare and keeping freerange egg prices within reach of most Australians. ${ }^{81}$

Here Coles takes on the language of a governing authority who consults with all the stakeholders, balances and accounts for all the competing values and interests, and then develops its own clear standard in the public (or in this case the consumer) interest. As Jackie Healing, Head of Quality and Responsible Sourcing at Coles put it in a YouTube advertisement (that supported a television and magazine advertising campaign),

Well, the first thing we had to do was talk to our customers and talk to the producers so that we could even understand what was possible. We knew that we wanted to take the birds out of cages, we also knew that we had to get a good value product for

\footnotetext{
${ }^{80}$ Meah and Watson (2013).

${ }^{81}$ The Advertiser (Adelaide) Online, 'Free-range eggs panned in Coles collision course http://www.adelaidenow.com.au/news/free-range-eggs-panned-in-coles-collision-course/storye6frea6u-1226388123417 7 June 2012.
} 
the customer. So we worked with the industry and came up with our own standard and we decided how much space we wanted the birds to have, we talked to the RSPCA, we wanted to have perches, we still wanted to have plenty of room to move around, but you've gotta make sure the animals are healthy and you've gotta make sure that the eggs are still being produced at a price that the customers can afford... ${ }^{82}$

Coles also points out that this governance of free range is giving both consumers and producers "certainty" in an unstable and contested terrain. Jackie Healing comments in a media report: "We've done more to clarify stocking densities in free-range systems in this country than has ever been done before". ${ }^{83}$

As the quotations above indicate, it is price that is key, with supermarkets attempting to meet consumer demands for both higher welfare standards and a low price. In 2009 and 2010 both major supermarkets had already announced that they were "promoting" the "choice" of cage free by dropping the price of own brand "free range" eggs to around the same price as previously offered for barn eggs. ${ }^{84}$ Their statements made it clear they saw themselves as responding to consumer demand for both "free range" and cheap eggs. A 2010 Coles media release put it this way:

Prices on Coles Brand free range eggs will fall in all States from today with cuts of at least $18 \%$. The move follows a clear message from customers that they want to buy free range eggs instead of caged eggs but are prevented from doing so because of the cost. Latest research shows that $95 \%$ of Coles customers would switch to free range if the price was lower...This is part of our ongoing campaign to offer all customers quality fresh food, ethically produced and at affordable prices. ${ }^{85}$

The perceived need to keep prices low is also what makes supermarket free range vulnerable to criticism from both sides - producers and consumers. The supermarkets realise that many consumers want to express their values and identity by choosing cage free. But the pastured production methods developed by alternative free range farmers are expensive and generally do not yet operate at a scale that can provide reliable mass supply. ${ }^{86}$ The most obvious alternative, "barn" production, where hens

82 Coles, Transcript of "Introduction to Sow Stall Free Pork \& Cage Free Eggs - Coles" Curtis Stone $\&$ Jackie Healing discuss the Sow Stall Free Pork \& Cage Free Eggs initiatives at Coles

http://www.youtube.com/watch?v=af1MqQGW61U\&NR=1\&feature=endscreen. 8 January 2013.

${ }^{83}$ Melissa Fyfe and Royce Millar (2013) 'Coles tackled on free range plan’ The Sydney Morning Herald http://www.smh.com.au/environment/animals/coles-tackled-on-freerange-plan-201303032fegm.html\#ixzz2pmwxhleT 4 March 2013.

${ }^{84}$ The Sydney Morning Herald (Online), 'Coles to Cut Price of Free Range Eggs' http://www.smh.com.au/environment/animals/coles-to-cut-price-of-freerange-eggs-2010111817yqe.html 18 November 2010; The Daily Telegraph (Online), 'Shopping Giant Woolworths Goes Free Range with Eggs' http://www.dailytelegraph.com.au/news/shopping-giant-woolworths-goes-freerange-with-eggs/story-e6freuy9-1225761152146 14 August 2009.

85 Coles, 'Cuts Free Range Egg Prices to Help Customers Switch from Caged Eggs: 95\% of Customers Say Price is Key', https://www.coles.com.au/Portals/0/content/pdf/News/Free\%20Range\%20Eggs\%20Media\%20Release $\% 20$ National.pdf 18 November 2010.

86 See also Richards et al (2013), pp 238-9. The alternative free range farmers and accreditation 
are housed in large barns but not confined in cages, does not appeal to many consumers. ${ }^{87}$ Indeed industry and activist spokespersons consulted for this research commented that most consumers do not seem to understand "barn" production. In effect, then, Coles and Woolworths' exercise of authority is likely to result in a situation where producers are forced to bring supermarket egg production out of the cage but only into an "aviary" or barn system that provides minimal outdoor access and few other conditions that consumers might associate with free range production systems. $^{88}$

Egg producers have claimed that when Coles and Woolworths dropped the price of "free-range" eggs in 2009 and 2010, they did so by reducing the number of both cage and free-range egg suppliers they used, while squeezing the prices paid to the remaining producers. ${ }^{89}$ Coles and Woolworths' stocking density of 10, 000 hens per hectare may be half that (controversially) proposed by the Egg Corporation but it is still many times the 1500 per hectare in the Model Code and the even lower densities in alternative standards. The ability of hens to access the outside range area, standards for the attractiveness and management of the ranging area, and the practice of beak trimming, are still not addressed. ${ }^{90}$ Rather Coles and Woolworths have focused attention on the idea that "free range" hens should have access to the outdoors and that there needs to be clarity about stocking density. The supermarkets do not actively promote sustainable farming practices nor aspirational animal welfare standards. Indeed we might label such supermarket standard "free range" eggs as "barnyard" eggs, a barn with an exercise yard; or "enriched barn" eggs, an enriched barn experience compared with completely confined chickens; or "barn-centric" eggs, which acknowledges where the chickens spend the majority of their time each day. Supermarkets can do this because most consumers do not have the capacity, time or inclination to find out how eggs are really produced. ${ }^{91}$

\section{Acquiring the ethical halo of approval by animal welfare advocacy organisations}

Both supermarket chains seek to appropriate the "ethical halo" of trusted animal welfare advocacy organisations, such as the RSPCA and Animals Australia, by seeking their endorsements. Coles emphasise that it had consulted with both animal

\footnotetext{
agencies interviewed for this research made these points.

${ }^{87}$ The Egg Corporation's 2013 Annual Report shows that barn eggs account for only $10 \%$ of egg sales: AECL, 'AECL Annual Report 2013'. Australian Egg Corporation Limited. http://www.aecl.org/assets/About-us/AECL-Annual-Report-2013-final.pdf.

${ }^{88}$ See Choice (2013) citing their own research on consumer expectations about "free range".

${ }^{89}$ ABC News Online, 'Free range egg suppliers avoid the supermarket' http://www.abc.net.au/sitearchive/rural/news/content/201103/s3157987.htm, 8 March 2011; Weekly Times, 'Egg growers crack it' http://www.animalwelfarelabels.org.au/index.php/news/108-the-argument-for-a-national-definitionfor-free-range-eggs 19 August 2009.

${ }^{90}$ VFF, 'HenCare Egg Standards' http://www.vff.org.au/vff/Documents/egg\%20standards.pdf; VFF, 'Coles Backs VFF's HenCare QA Program (Media Release) http://www.vff.org.au/vff/Media_Centre/Coles\%20backs\%20VFF\%E2\%80\%99s\%20HenCare\%20QA $\% 20$ program.aspx.

${ }^{91}$ See Meah and Watson (2013), Miele and Evans (2010).
} 
welfare groups and industry before deciding on its free range standard. Both Coles and Woolworths' websites highlight the RSPCA approved products sold in their stores. ${ }^{92}$ The RSPCA's endorsement of supermarket products, particularly own brand products, helps legitimate the supermarkets' animal welfare governance. Coles has received a RSPCA Good Egg Award Commendation for its announcement of plans to remove cage eggs from shelves in $2010 .^{93}$ When it made its 2012 announcement that no own brand cage eggs would be sold from the beginning of 2013, Coles also received the public endorsements of the RSPCA and Animals Australia as its website proclaims. Similarly, when in 2009 Woolworths pledged to reduce cage egg lines and signalled the potential of phasing out battery cage eggs altogether, the RSPCA showed support for Woolworths, saying it was a move toward greater hen welfare. ${ }^{94}$ After Woolworths' 2013 announcement, animal rights groups Voiceless and Animals Australia were also reported as applauding their move. ${ }^{95}$

Yet this ethical halo is precarious. The animal welfare and consumer advocacy NGOs that have led the hen welfare and free range issue have still been willing to criticise and discredit the supermarkets. Since Coles announced that its standard allows up to 10,000 hens per hectare outdoors, the RSPCA and Animals Australia have subsequently cast doubt that Coles' "free range" should be labelled "free-range" at all. ${ }^{96}$ The Humane Society International has also initiated a complaint to the ACCC that Coles' free range is misleading. ${ }^{97}$ There is an ongoing contest over the legitimacy of supermarket's regulatory authority, and whether governments should intervene to regulate.

In 2013 the peak Australian consumer association, Choice, crystallised much of this contestation in a "super complaint" to NSW Fair Trading complaining that "the lack of an enforceable standard [for free range egg claims] means that many products labelled free-range are produced under conditions that are substantially inconsistent

\footnotetext{
${ }^{92}$ See also RSPCA, 'Coles Barn Laid Eggs’ http://www.rspca.org.au/shophumane/rspcaproducts/eggs/coles-barn-laid/ 2011.

${ }^{93}$ Australian Food News, 'RSPCA Awards 'Good Eggs', http://www.ausfoodnews.com.au/2010/12/01/rspca-awards-good-eggs.html, 1 December 2010.
}

94 Green Lifestyle Magazine, 'Issue of free-range eggs cracked at Woolworths' . http://www.greenlifestylemag.com.au/news/1523/issue-free-range-eggs-cracked-woolworths 19 August 2009. See also RSPCA, 'RSPCA Welcomes Woolworths Egg Shift' http://www.rspca.org.au/news/rspca-welcomes-woolworths36egg-shift.html 2009.

95 The Herald Sun (Online), 'Woolies Caged Eggs Move Angers Farmers' http://www.heraldsun.com.au/news/breaking-news/woolies-to-phase-out-sale-of-caged-eggs/storyfni0xqi4-1226732679709 6 October 2013; The Sydney Morning Herald (Online), 'Farmers Angry at Woolies’ Eggs Ban' http://www.smh.com.au/national/farmers-angry-at-woolies-eggs-ban-201310042uzr6.html 5 October 2013.

${ }^{96}$ Melissa Fyfe and Royce Millar (2013) 'Coles tackled on free range plan' The Sydney Morning Herald http://www.smh.com.au/environment/animals/coles-tackled-on-freerange-plan-201303032fegm.html\#ixzz2pmwxhleT 4 March 2013; ABC Rural News Online, 'RSPCA has reservations about Coles' free range egg push' http://www.abc.net.au/sitearchive/rural/news/content/201303/s3702747.htm 4 March 2013.

${ }^{97}$ Humane Society International, 'Coles intensifies 'free range' egg production duping customers and cramming thousands of hens into sheds' http://www.hsi.org.au/?catID=1271 4 March 2013. 
with voluntary standards and consumer expectations". ${ }^{98}$ NSW Fair Trading responded by recommending the creation of a national "information standard" under the Australian Consumer Law to define the meaning of free range and mandate what information is shown on labels. ${ }^{99}$ Both national and state governments have been very reluctant to regulate free range labelling in the past, ${ }^{100}$ but appear to have accepted the need for a code based in Australian Consumer Law, which is administered and enforced by the politically powerful ACCC, aimed at avoiding misleading and deceptive conduct in free range labelling. ${ }^{101}$

\section{Seeking trust via celebrity chef spokespersons}

Finally, both Coles and Woolworths use celebrity chefs to generate consumer trust by appropriating the credibility attached to these celebrities. ${ }^{102}$ Woolworths latest animal welfare initiatives were part of a new marketing campaign in which Woolworths announced that that they will "partner with a much-loved chef and fresh food campaigner," the UK television chef Jamie Oliver to introduce changes including the phasing out of cage eggs. ${ }^{103}$ Oliver has a global reputation for activism to change the food system and for advocating for change to fresh, quality ingredients, cooking from scratch in preference to over processed, over industrialised food, and a generally ethical approach. ${ }^{104}$ Indeed Oliver's espousal of higher welfare animal food products has in the past attracted extra scrutiny and media attention to brands with which he is associated. ${ }^{105}$

In Coles' animal welfare advertising Curtis Stone represents the everyman consumer and chef (in contrast to Heston Blumenthal, who represents high end innovation in Woolworths lines). In their marketing campaigns Jackie Healing, Head of Quality and Responsible Sourcing, explains Coles' sourcing policies to Curtis (and thus to the consumer), as in the following extract from Coles' YouTube advertisements for own brand free range eggs:

Curtis: ... this is something close to my heart, I grew up with chickens in my backyard and the thought of them being in tiny little cages makes me a little sad, so what is it, we've stopped all of the production of cage eggs?

Jackie: Yeah so for Coles brand eggs we did have some products in cages and the birds only have a little bit of space like this (holds hands out to show space, making box shape

\footnotetext{
${ }^{98}$ Choice (2013) pp 4.

${ }^{99}$ NSW Fair Trading Authority (2013) pp 21.

${ }^{100}$ See e.g. PRFLLP (2011).

${ }^{101}$ See discussion above at text accompanying notes 77 and 78.

102 Dixon (2007); Dixon \& Banwell (2004).

103 ABC Rural, 'Jamie Oliver partners Woolies to stop selling caged-hen eggs' 4 October 2013, http://www.abc.net.au/news/2013-10-04/nrn-woolies-caged-eggs/4998380

${ }^{104}$ Byrne et al (2003).

${ }^{105}$ See for example, http://www.telegraph.co.uk/news/celebritynews/9638026/Jamie-Olivers-chickenscome-home-to-roost.html
} 
about $30 \mathrm{~cm}$ wide) and we've taken all of the birds making eggs for Coles out of those cages and they're either in big barns or they're free to roam in pastures all around.

Curtis: Then we went out to a farm recently.

Jackie: We did last week.

Curtis: Free range, so they have access to the outside all the time. ${ }^{106}$

In other marketing material, Stone advertises Coles own brand animal welfare initiatives and provides recipes and advice.

Yet Jamie Oliver and Curtis Stone are far from the final word on how consumers and activists would like to see supermarket food change. Alternative free range egg standards continue to proliferate in competition with Coles and Woolworths' own brand standards. Consumers continue to flock to farmers markets and organic stores for alternatively produced food including eggs. Australian farmers' markets more than doubled between 2004 and 2011 and accounted for 7 per cent of fresh food sales. ${ }^{107}$ As Table 1 shows, alternatively accredited eggs are much more likely to be found for sale at these farmers markets and specialist stores and consumers will also often receive more direct information about the production of eggs in these places. ${ }^{108}$ There is also anecdotal evidence of a renaissance of backyard egg farming in the suburbs of Australia.

\footnotetext{
106 See note 22 above.

${ }^{107}$ Er et al (2011), pp 50-57.

${ }^{108}$ See Parker (2013).
} 


\section{CONCLUSION}

Supermarkets have been one of the drivers and beneficiaries of unsustainable and inhumane food production and consumption since the mid twentieth century. ${ }^{109}$ Friedmann and McMichael have suggested that the combination of the emerging political authority of supermarkets and the concerns of consumers with ethical, green and quality issues is leading to a new "corporate food regime". In this corporate food regime various environmental, social and economic justice concerns may be mainstreamed by retailers eager to respond to consumer sentiment. ${ }^{110}$ Certainly, as this paper has shown, supermarkets' inclusion of products with higher environmental or animal welfare standards can enhance their image as responsible and sustainable retailers and burnish their ethical haloes, even while they continue to sell food produced largely via intense industrial production methods.

The two supermarket giants have been complicit in instituting a watered-down standard for "free-range" egg production. In doing so they perpetuate a misleading understanding of the conditions under which most of the so-called "free-range" eggs in Australia are produced. They might also undermine the market for more genuine "free-range" eggs by driving down prices, denying a retail outlet to more alternative producers, and dominating the regulatory space for "free range" private standards with the apparent legitimacy of their authority. Thus the supermarkets are deploying regulatory and discursive power to mainstream animal welfare values in a way that appropriates $^{111}$ the notion of "free range". This is done to further entrench their own concentration of market power through the provision of cage free own brand eggs. Their control over both price and quality then further entrenches intense industrial production methods in egg production ${ }^{112}$ by watering down regulatory standards and obfuscating public understanding of "free range". ${ }^{113}$

Higher government regulatory standards for both animal food production and labelling, and ongoing enforcement against misleading labelling (as proposed by the $\mathrm{ACCC}^{114}$ ) are an important way to contest supermarket political and market power. Indeed it would be wise to address the substantive issues at stake in concentrated supermarket economic and political power - namely the entrenchment of the intense industrial food system and its various impacts on humans, animals and ecosystems via substantive critique and regulatory action that moves the goalposts in the broader food system. Focusing regulatory attention on catching supermarkets out on specific instances of bullying suppliers, or misleading consumers may be important short term strategies to ameliorate supermarket misuse of their market power. More profound

\footnotetext{
${ }^{109}$ Fuchs \& Clapp (2009); Lang \& Heasman (2004).

${ }^{110}$ Friedmann (2005); McMichael \& Friedmann (2007); see also Smith et al (2010).

111 Jackson et al (2007).

${ }^{112}$ As has previously occurred with "organic" production in the US: see Guthman (2003); Jaffee and Howard (2009); Lockie (2009).

${ }^{113}$ See Parker et al (2013).

114 The ACCC has indicated enforcement against misleading credence claims on food labels is a priority area: Sims (2013).
} 
and lasting change will occur only if government and civil society are willing to go further and tackle the political substance of supermarkets emerging regulatory and cultural power as "food authorities". This would require governments and civil society to step back into the regulatory spaces for animal welfare, agrifood production and retail labelling rather than leaving these matters largely to food corporations, especially retailers like the supermarkets and fast food chains. 


\section{REFERENCES}

ACCC (2008) Report of the ACCC Inquiry into the Competitiveness of Retail Prices for Standard Groceries, Commonwealth of Australia

ACCC (2012) Initial assessment of Certification Trade Mark application CTM1390450 Filed by the Australian Egg Corporation Limited. Canberra: Commonwealth of Australia.

ACCC (2013) Statement to the Senate Economics Estimates Committee (Additional Budget Estimates) 13 February 2013

Appleby, Michael C (2003) 'The European Union Ban on Conventional Cages for Laying Hens: History and Prospects' 6 Journal of Applied Animal Welfare Science 103

Appleby, M.C., and B.O. Hughes. 1991. Welfare of laying hens in cages and alternative systems: Environmental, physical and behavioural aspects. World's Poultry Science Journal 47(2): 109-128.

Bain, C., B. Deaton and L. Busch (2005) 'Reshaping the agri-food system: The role of standards, standard makers and third-party regimes' in G Lawrence and Vaughan Higgin (eds) Agricultural Governance: Globalization and the new politics of regulations, Routledge

Burch, David and Geoffrey Lawrence (2005) 'Supermarket own brands, supply chains and the transformation of the agri-food system’ 13(1) International Journal of Sociology and Agriculture 1

Burch, David and Geoffrey Lawrence (2007) 'Understanding supermarkets and agri-food supply chains' in David Burch and Geoffrey Lawrence (eds) Supermarkets and Agri-Food Supply Chains: Transformations in the Production and Consumption of Foods, Edward Elgar

Burch, D., B. Lawrence and L. Hattersley (2012) 'Watchdogs and ombudsmen: monitoring the abuse of supermarker power' 30(2) Agriculture and Human Values 259

Burch, David, Jane Dixon, and Geoffrey Lawrence (2013) 'Introduction to symposium on the changing role of supermarkets in global supply chains; from seedling to supermarket: agri-food supply chains in transition'30 Agriculture and Human Values 215.

Byrne, Angela, Maureen Whitehead, and Steven Breen (2003) 'The naked truth of celebrity endorsement' 105 British Food Journal 288

Cashore, Benjamin, Graeme Auld, and Stefan Renckens (2011) 'The Impact of Private, Industry and Transnational Civil Society Regulation and their Interaction with Official Regulation' in Christine Parker and Vibeke Lehmann Nielsen (eds) Explaining Compliance: Business Responses to Regulation, Edward Elgar.

Challies, Edward (2012) 'The limits to voluntary private social standards in global agri-food system governance’ 20 International Journal of Sociology of Agriculture \& Food 175

Choice (2013) Free-range egg claims in NSW: Super-complaint to NSW Fair Trading Choice Australia http://www.fairtrading.nsw.gov.au/biz_res/ftweb/pdfs/About_us/Choice_super_complaint_on_freerange egg_claims.pdf

Clapp, Jennifer (2012) Food, Polity Press

Council of the European Union (1999) Council Directive 1999/74/EC of 19 July 1999 laying down minimum standards for the protection of laying hens, Official Journal of the European Communities L:203/53

Council of the European Union (2008) Council Directive 2008/120/EC of 18 December 2008 laying down minimum standards for the protection of pigs (Codified version), Official Journal of the European Communities L: 47/5 
Davey, Stephen and Carol Richards (2013) 'Supermarkets and private standards: unintended consequences of the audit ritual' 30(2) Agriculture and Human Values 271

Davis, P. and A. Reilly (2010) 'Market power, market outcomes and remedies in the UK groceries market' 41 Agricultural Economics 93

Dixon, Jane (2007) 'Supermarkets as new food authorities' in David Burch and Geoffrey Lawrence (eds) Supermarkets and Agri-Food Supply Chains, Edward Elgar.

Dixon, Jane and Cathy Banwell (2004) 'Re-embedding trust: Unravelling the construction of modern diets' 14 Critical Public Health 117

Duncan, Ian J.H. (2001) 'Animal Welfare Issues in the Poultry Industry: Is There A Lesson to be Learned?’ 4 Journal of Applied Animal Welfare Science 207

Er, Dawn, Bill Binks, and Saan Ecker (2011) 'Social and Economic Dimensions of Farmers' Markets in Australia'in Australian Government Department of Agriculture, Fisheries and Forestry, Australian Food Statistics 2010-2011, , Commonwealth of Australia

Friedmann, Harriet (2005) 'From colonialism to green capitalism: Social movements and the emergence of food regimes' in Frederick Buttel and Philip McMichael (eds) New Directions in the Sociology of Global Development, Elsevier

Fuchs, Doris and Jennifer Clapp (2009) Corporate Power in Global Agrifood Governance Massachusetts Institute of Technology

Fuchs, Doris, Agni Kalfagianni and Tetty Havinga (2011) 'Actors in Private Food Governance: The Legitimacy of Retail Standards and Multistakeholder Initiatives with Civil Society Participation' 28(2) Agriculture and Human Values 353

Fulponi, Linda (2006) 'Private voluntary standards in the food system: The perspective of major food retailers in OECD countries' 31(1) Food Policy 1

Goodman, David (2003) 'The quality ‘turn'and alternative food practices: reflections and agenda' 19 Journal of Rural Studies 1

GSAAGD (2013) Industry Code for Growing Free Range Eggs in South Australia (Discussion Paper) Government of South Australia Attorney-General's Department,

Guthman, Julie (2003), 'Fast food/organic food: reflexive tastes and the making of 'yuppie chow' $4(1)$ Social and Cultural Geography 45

Harvey, Mark, Andrew McMeekin, and Alan Warde (eds) (2004) Qualities of Food, Manchester University

Hattersley, Libby, Bronwyn Isaacs, and David Burch (2013) 'Supermarket power, own-labels, and manufacturer counterstrategies: international relations of cooperation an competition in the fruit canning industry' 30 Agriculture and Human Values 225

Jackson, P., P. Russell and N. Ward (2007) 'The appropriation of 'alternative' discourses by 'mainstream' food retailers' in Damina Maye, Lewis Holloway and Moya Kneafsey (eds) Alternative Food Geographies: Representation and Practice, Elsevier

Jaffee, Daniel and Philip H. Howard (2010) 'Corporation co-optation of organic and fair trade standards’ 27 Agriculture and Human Values 387

King, Brayden G., and Nicholas A. Pearce (2010) 'The Contentiousness of Markets: Politics, Social Movements, and Institutional Change in Markets’ 36 Annual Review of Sociology 249 
Konefal, Jason, Michael Mascarenhas, and Maki Hatanaka (2005) 'Governance in the global agro-food system: backlighting the role of transnational supermarket chains' 22 Agriculture and Human Values 291

Lang, Tim, and Michael Heasman (2004) Food Wars: The Global Battle for Mouths, Minds and Markets, Earthscan

Lyons, Kristen (2007) 'Supermarkets as Organic Retailers: Impacts for the Australian Organic Sector, (Chapter 7)' in Burch, David. \& Geoffrey Lawrence (eds.) Supermarkets and Agrifood Supply Chains: Transformations in the Production and Consumption of Foods, Edward Elgar

Matheny, Gaverick, and Cheryl Leahy (2007) 'Farm-animal Welfare, Legislation and Trade' 70 Law and Contemporary Problems 325

McEwen, Graeme (2011) Animal law: principles and frontiers, http://bawp.org.au/animal-law-e-book/

McMichael, Philip, and Harriet Friedmann (2007) 'Situating the 'Retailing Revolution' in David Burch and Geoffrey Lawrence (eds) Supermarkets and Agri-food Supply Chains: Transformations in the Production and Consumption of Foods, Edward Elgar

Meah, Angela, and Matt Watson (2013) 'Cooking up Consumer Anxieties about "Provenance" and "Ethics": Why it Sometimes Matters where Foods Come from in Domestic Provisioning' 16 Food, Culture and Society: An International Journal of MultidisciplinaryResearch 495.

Merrett, Alexandra, and Rhonda L Smith (2012) 'The State of Competition: Crying Over Spilt Milk: Buyer Power and the Rise of Private Labels' 1 The State of Competition 1

Miele, Mara, and Adrian Evans (2010) 'When Foods Become Animals: Ruminations on Ethics and Responsibility in Care-full Practices of Consumption' 13 Ethics, place and environment: A journal of philosophy and geography 171.

Miele, M., J. Murdoch and E. Roe (2005) 'Animals and ambivalence: Governing farm animal welfare in the European food sector' in G Lawrence and Vaughan Higgins (eds) Agricultural governance: Globalization and the new politics of regulation, Routledge

Mortimer, Gary (2013) 'FactCheck: is our grocery market one of the most concentrated in the world?' The Conversation, 12 August 2013 http://theconversation.com/factcheck-is-our-grocery-market-one-ofthe-most-concentrated-in-the-world-16520

NSW Fair Trading Authority (2013) NSW Fair Trading Response to CHOICE Super Complaint on Free-Range Egg Claims Government of NSW

http://www.fairtrading.nsw.gov.au/biz_res/ftweb/pdfs/About_us/Response_to_choice_super_complaint on_free-range_egg_claims.pdf

O’Sullivan, Siobhan (2011) Animals, Equality and Democracy, Palgrave Macmillan

Outlaw, Kiera (2012) 'Eggs Farming in Australia' IBISWorld (IBISWorld Industry Report A0142) http://www.ibisworld.com.au/industry/default.aspx?indid=1834

PRFLLP (Panel for the Review of Food Labelling Law and Policy) (2011) 'Labelling Logic' - The Final Report of the Review of Food Labelling Law and Policy, Commonwealth of Australia

Parker, Christine (2013) 'Voting with your fork? Industrial free range eggs and the regulatory construction of consumer choice' 649 Annals of the American Academy of Social and Political Science 52

Parker, Christine, Carly Brunswick and Jane Kotey (2013) 'The happy hen on your supermarket shelf: what choice does industrial strength free range represent for consumers?' 10(2) Bio Ethical Inquiry 165

Primary Industries Standing Committee (2002) Model code of practice for the welfare of animals: 
domestic poultry (4 $4^{\text {th }}$ edition), CSIRO Publishing

Pickett, Heather, (2003) Industrial Animal Agriculture, Compassion in World Farming

Richards, Carol, Geoffrey Lawrence, and David Burch (2011) 'Supermarkets and Agro-industrial foods' 14 Food, Culture and Society 29

Richards, Carol, Geoffrey Lawrence, Mark Loong and David Burch (2012) 'A toothless chihuahua? The Australian Competition and Consumer Commission, neoliberalism and supermarket power in Australia' 21 Rural Society 250

Richards, Carol, Hilde Bjorkhaug, Geoffrey Lawrence, and Emmy Hickman (2013) 'Retailer-driven agricultural restructuring - Australia, the UK and Norway in comparison' 30(2) Agriculture and Human Values 235

Round, David K. (2006) 'The power of two: squaring off with Australia's largest supermarket chains' 60 The Australian Journal of Agricultural and Resource Economics 51

Scott, Colin (2001) 'Analysing regulatory space: fragmented resources and institutional design' Public Law 329

Sharman, Katrina (2009) 'Farm animals and welfare law: an unhappy union' in Peter Sankoff and Steven White (eds) Animal Law in Australasia: A New Dialogue, Federation Press

Shamir, Ronen (2008) 'Corporate Social Responsibility: Towards A New Market-Embedded Morality?’ 9 Theoretical Inquiries in Law 371

Sims, Rod 'Thoughts on market concentration issues', Address to the Australian Food and Grocery Council Industry Leaders Forum, Canberra, 30 October 2013

Smith, Kiah, Geoffrey Lawrence and Carol Richards (2010) 'Supermarkets' governance of the agrifood supply chain: Is the corporate environmental food regime evident in Australia?' 17 International Journal of Sociology of Agriculture \& Food 140

Standing Committee on Agriculture and Resource Management (SCARM) (2000) Synopsis report on the review of hen housing and labeling of eggs in Australia, Commonwealth of Australia

Taylor, Madeline (2013) 'Wrestling with Giants - a critical account of supermarket power and competition law in Australia and the United Kingdom' 41 Australian Business Law Review 270

Weber, Klaus, Kathryn L. Heinze, and Michaela Desoucey (2008) 'Forage for Thought: Mobilizing Codes in the Movement for Grass-Fed Meat and Dairy' 53 Administrative Science Quarterly 529

Weis, Tony (2007) The Global Food Economy: The Battle for the Future of Farming, Zed Books

Wilkinson, John (2002) 'GMOs, organics and the contested construction of demand in the agrifood system’ 10(2) International Journal of Sociology of Agriculture and Food 
Table 1: Major private standards for free range egg production in Australia

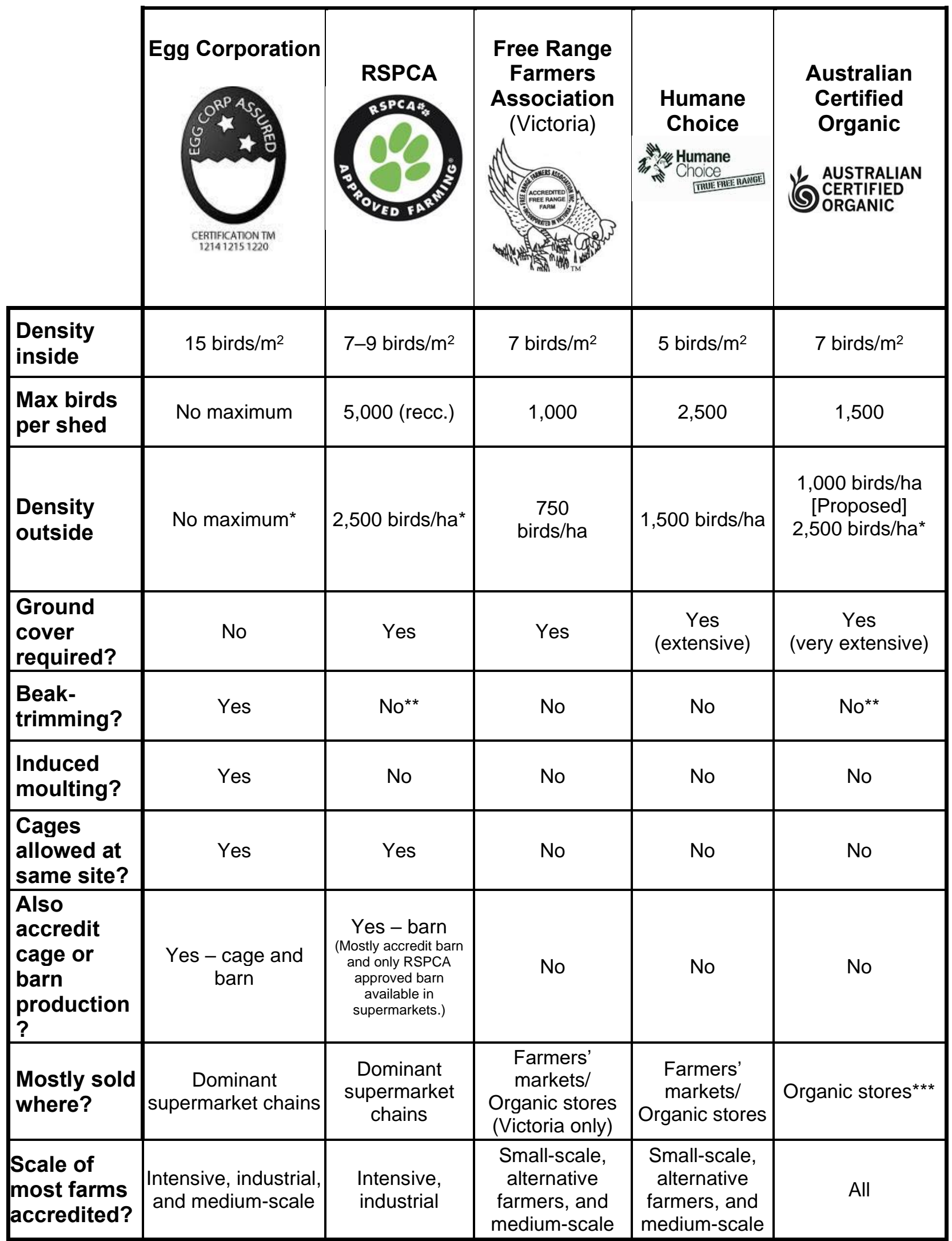

Information in table based on publicly available information from each of the relevant agencies. Full details available from the first author on request. 
* Where there is rotation of ranges available for birds. Standards for how often and in what conditions rotation must occur vary and especially in the case of Egg Corp Assured are minimal and not very specific. In each case the maximum without rotation is 1,500 birds per hectare - but interviews suggest most producers claim they do use rotation.

${ }^{* *}$ Exceptions may be specifically allowed by the accrediting organization.

${ }^{* * *}$ Also available to a limited extent in dominant supermarket chains and farmers' markets in ACT and NSW. 
Table 2: Free Range Eggs Available in Supermarkets that show Outdoor Stocking Density, and when Stocking Density Appeared on Label 20122013*

\begin{tabular}{|c|c|c|c|c|}
\hline & Outlet & $\begin{array}{l}\text { Outdoor } \\
\text { stocking } \\
\text { density }\end{array}$ & $\begin{array}{l}\text { Claims made on/in carton } \\
\text { relevant to stocking density }\end{array}$ & $\begin{array}{l}\text { Does the label } \\
\text { display a logo or } \\
\text { accreditation? }\end{array}$ \\
\hline \multicolumn{5}{|c|}{ Brands showing outdoor stocking density since 2012 before Coles announcement } \\
\hline $\begin{array}{l}\text { Family } \\
\text { Homestead } \\
\text { Free Range }\end{array}$ & $\begin{array}{l}\text { Coles } \\
\text { Supermarket- } \\
\text { but available in } \\
\text { fewer outlets in } \\
2013 \text { than } \\
2012\end{array}$ & 750/ha & $\begin{array}{l}\text { 'No factory farming.... Low stocking } \\
\text { density...750 chickens per } \\
\text { hectare compared with } 20,000- \\
50,000 \text { per hectare; ...No meat } \\
\text { meal or colour additives; ...No de- } \\
\text { beaking or beak trimming; } \\
\text {...Accredited \& independently } \\
\text { audited by the Free Range Farmers } \\
\text { Association of Victoria.' }\end{array}$ & $\begin{array}{l}\text { Free Range Farmers } \\
\text { Association of Victoria }\end{array}$ \\
\hline $\begin{array}{l}\text { McLean's } \\
\text { Run Free } \\
\text { Range } \\
\text { (Subsidiary } \\
\text { of Sunny } \\
\text { Queen) }\end{array}$ & $\begin{array}{l}\text { Woolworths } \\
\text { Supermarket }\end{array}$ & 1500/ha & $\begin{array}{l}\text {...our farms have the highest } \\
\text { commitment to hen welfare with } \\
\text { only } 1,500 \text { hens per hectare - } \\
\text { that's one hen per } \mathbf{6 m}^{2} ! \\
\ldots \text {... McLean's Run farms are owned } \\
\text { by Australian farmers, and are fully } \\
\text { Free Range Accredited. That } \\
\text { means they're regularly inspected } \\
\text { by independent auditors, so you } \\
\text { can be sure the highest standards } \\
\text { of hen welfare and egg quality are } \\
\text { always maintained.' }\end{array}$ & $\begin{array}{l}\text { "Open Range" logo on } \\
\text { carton, but not part of } \\
\text { any scheme }\end{array}$ \\
\hline \multicolumn{5}{|c|}{ Brands showing outdoor stocking density since 2013 after Coles announcement } \\
\hline $\begin{array}{l}\text { Coles Brand } \\
\text { Free Range }\end{array}$ & Coles & $\begin{array}{l}10,000 / \mathrm{ha} \\
(\max )\end{array}$ & $\begin{array}{l}\text { 'Coles Australian Free Range } \\
\text { Eggs...From hens free to naturally } \\
\text { roam and perch... When Coles } \\
\text { Brand says Free Range, it means: } \\
\text { a maximum of 10,000 hens per } \\
\text { hectare outdoors.' }\end{array}$ & \\
\hline $\begin{array}{l}\text { Woolworth's } \\
\text { Select Free } \\
\text { Range }\end{array}$ & Woolworths & $\begin{array}{l}10,000 / \mathrm{ha} \\
(\max )\end{array}$ & $\begin{array}{l}\text { 'Free Range Fresh Farm Eggs' } \\
\text { 'Laid by hens that are free to roam } \\
\text { outdoors by day and nest in barns } \\
\text { at night...1 bird per metre } \\
\text { squared outdoors equals } \mathbf{1 0 , 0 0 0} \\
\text { birds per hectare...A maximum } \\
\text { hen stocking density of } 10,000 \\
\text { birds per hectare where hens are } \\
\text { regularly rotated onto fresh range } \\
\text { areas and some continuing fodder } \\
\text { cover is provided.' }\end{array}$ & No \\
\hline
\end{tabular}




\begin{tabular}{|c|c|c|c|c|}
\hline & Outlet & $\begin{array}{l}\text { Outdoor } \\
\text { stocking } \\
\text { density }\end{array}$ & $\begin{array}{l}\text { Claims made on/in carton } \\
\text { relevant to stocking density }\end{array}$ & $\begin{array}{l}\text { Does the label } \\
\text { display a logo or } \\
\text { accreditation? }\end{array}$ \\
\hline $\begin{array}{l}\text { Eco Eggs (H } \\
\text { \& L } \\
\text { Premium } \\
\text { Free Range } \\
\text { Egg Farms) }\end{array}$ & Woolworths & $20,000 / \mathrm{ha}$ & $\begin{array}{l}\text { 'Free Range Eggs: Birds in free- } \\
\text { range systems are housed in sheds } \\
\text { and have access to an outdoor } \\
\text { range... Ecoeggs are certified free } \\
\text { range, check our website } \\
\text { ChookCam to see our happy hens } \\
\text { in action. Our hens range outside } \\
\text { at only } 2 \text { hens p/m2, graze on } \\
\text { open pastures and eat a special } \\
\text { balanced diet of select grains } \\
\text { boosted with natural supplements } \\
\text { rich in good Omega fats and certain } \\
\text { essential vitamins. We think happy, } \\
\text { healthy hens produce nutritious, } \\
\text { great tasting eggs.' }\end{array}$ & $\begin{array}{l}\text { Yes: Egg Corp } \\
\text { Assured }\end{array}$ \\
\hline \begin{tabular}{|l} 
Farm Pride \\
Free Range
\end{tabular} & $\begin{array}{l}\text { Woolworths } \\
\text { Supermarket, } \\
\text { Coles } \\
\text { Supermarket } \\
\text { and one IGA }\end{array}$ & $\begin{array}{l}\text { less than } \\
10,000 / \text { ha }\end{array}$ & $\begin{array}{l}\text { 'Free Range Eggs from Free Range } \\
\text { Farms where chickens roam } \\
\text { free...<1 bird per square metre } \\
<10,000 \text { birds per hectare } \\
\text { maximum density outside.' }\end{array}$ & \\
\hline
\end{tabular}

* Based on visits to supermarkets in a variety of locations around Melbourne in February and March 2012; and again to the same supermarkets in September and October 2013. Coles announced all own brand eggs would be free range or barn with an outdoor stocking density of 10, 000 hens per hectare for free range in December 2012. There were 17 free range or organic brands available in Coles and Woolworths at each time: 16 of the brands remained the same; and Essential Foods (Farm Pride) were availabe only in 2012 Macro Wholefoods Market organic eggs became available in 2013. 